\title{
ANÁLISE SOCIOLÓGICA SOBRE A PRÁTICA DO VÔLEI DE RUA EM CUIABÁ/MT
}

Recebido em: $15 / 11 / 2018$

Aceito em: 12/09/2019

\author{
Francisco Xavier Freire Rodrigues ${ }^{1}$ \\ Caroline Maria de Lima ${ }^{2}$ \\ Universidade Federal de Mato Grosso (UFMT) \\ Cuiabá - MT - Brasil
}

RESUMO: O artigo tratou do vôlei de rua em Cuiabá/MT como fenômeno sociológico. Procurou desvendar os componentes mediadores do vôlei de rua, bem como identificar os interesses de seus praticantes em Cuiabá/MT, além de evidenciar as histórias de vida de agentes sociais que constroem uma trajetória do lazer, ocupando os espaços comunitários, bairros e as ruas do centro urbano de Cuiabá/MT. A pesquisa buscou também traçar o perfil dos praticantes de vôlei de rua, diferenciar o vôlei de rua do vôlei de quadra e analisar as formas de sociabilidades e disputas em torno dos eventos e jogos de vôlei de rua. A questão norteadora da investigação foi a seguinte: Que estratégias delineiam as maneiras de fazer o "vôlei de rua" em Cuiabá/MT? Trata-se de uma pesquisa qualitativa e descritiva que se utilizou de entrevistas como técnica de coleta de dados. O aporte teórico utilizado é da sociologia contemporânea, os conceitos de campo e habitus de Bourdieu, e cultura e mediação cultural em Geertz, Barbero e Lamizet. O vôlei de rua média as relações sociais entre os atletas, sendo lazer, esporte e veículo produtor de sociabilidades. Dentro dos próprios relatos podemos perceber claramente as diferenças discursivas; uns mais conservadores ou resistentes, outros mais receptivos ao desconhecido, ao novo. Mas o fio condutor de todos os conflitos, provocador da ruptura ressignificante, reside naquele ato de expor publicamente o nome de jogadores que antes na quadra não tinham nenhuma relevância e no ambiente da rua (vôlei de rua) serem os reis da rua.

PALAVRAS CHAVE: Atividades de Lazer. Vôlei de Rua. Mediação Cultural. Cuiabá/MT.

\footnotetext{
${ }^{1}$ Professor Efetivo Associado II do Departamento de Sociologia e Ciência Política, Universidade Federal de Mato Grosso. Professor Permanente do Programa de Pós-Graduação em Sociologia. Professor Permanente do Programa de Pós-Graduação em Estudos de Cultura Contemporânea - PPGECCO/UFMT. Coordenador do GT Sociologia do Esporte da Sociedade Brasileira de Sociologia - SBS. Líder do Grupo de Estudos e Pesquisas em Esporte, Cultura e Sociedade - GEPECS CNPq/UFMT.

${ }^{2}$ Professora no Curso de Educação Física no Centro Universitário de Várzea Grande-MT (2014 - dias

2 Professora no Curso de Educação Física no Centro Universitário de Várzea Grande-MT (2014 - dias atuais). Professora da Rede Municipal de Santo Antônio de Leverger - MT (2015-dias atuais). Graduada em Educação Física pelo Centro Universitário de Várzea Grande -MT (2013). Graduada em Administração Geral pela Faculdade Afirmativo - MT (2008). Pós-Graduada em Docência do Ensino Superior pela EDUCARE Cuiabá - MT (2013/2014). Pós-Graduada em Estudos de Cultura Contemporânea, nível Mestrado pela UFMT - Cuiabá MT (2016/2018).
} 


\section{SOCIOLOGICAL ANALYSIS ON THE PRACTICE OF RUA VOLLEY IN CUIABÁ / MT}

ABSTRACT: The article deals with street volleyball in Cuiabá / MT as a sociological phenomenon. It seeks to uncover the mediating components of street volleyball, as well as to identify the interests of its practitioners in Cuiabá / MT, as well as to highlight the life histories of social agents who build a leisure path, occupying community spaces, neighborhoods and the streets of urban center of Cuiabá / MT. The research also sought to outline the profile of street volleyball practitioners, to differentiate street volleyball from volleyball court and to analyze the forms of sociability and disputes surrounding street volleyball events and games. The guiding question of the investigation was the following: What strategies outline the ways of doing "street volleyball" in Cuiabá / MT? This is a qualitative and descriptive research that used interviews as a data collection technique. The theoretical contribution used is contemporary sociology, Bourdieu's field concepts and habitus, and cultural culture and mediation in Geertz, Barbero and Lamizet. Street volleyball mediates social relations among athletes, being leisure, sport and sociability vehicle. Within the own reports we can clearly perceive the discursive differences; some more conservative or resistant, others more receptive to the unknown, to the new. But the guiding thread of all conflicts, which provoked the resigning rupture, lies in that act of publicly exposing the name of players who previously had no relevance in the court and in the street environment (street volleyball) are the kings of the street.

KEYWORDS: Leisure Activities. Street Volley. Cultural Mediation. Cuiabá/MT.

\section{Introdução}

O voleibol, esporte tão praticado no Brasil, seja nas quadras ou em outros espaços, se sustenta através do tempo presente como mediador cultural e prática esportiva, tanto de massa quanto popular, no caso desse estudo evidenciaremos a "Rua", como espaço dessa prática. Contudo, combinar o esporte de identidade nacional com aspectos da cultura local, se tornou elemento fundamental para compreender as diferentes dinâmicas sociais dos seus praticantes, assim o vôlei de rua tornou objeto de estudo do presente trabalho.

O voleibol tem um conjunto de particularidades se comparado a outras modalidades esportivas e culturais, proporcionando um estudo singular do meio social. 
Os aspectos culturais contidos na experiência de sua prática permitem uma boa análise sobre a identificação, significação e até o valor que ele tem na vida de seus personagens.

Este artigo apresentou uma análise sociológica sobre a prática do vôlei de rua em Cuiabá/MT. O problema investigado foi explicitado na seguinte questão: Que estratégias delineiam as maneiras de fazer o "vôlei de rua" em Cuiabá/MT? O objetivo do artigo foi investigar os significados do vôlei de rua para os praticantes e identificou e analisou as diferenças entre o vôlei de rua e o vôlei de quadra, além de que evidenciou as histórias de vida dos agentes sociais que constroem, através do "vôlei de rua", uma trajetória do lazer, ocupando os espaços comunitários, bairros e as ruas do centro urbano de Cuiabá/MT. A pesquisa traçou o perfil dos praticantes de vôlei de rua, diferenciou o vôlei de rua do vôlei de quadra e analisou as formas de sociabilidades e disputas em torno dos eventos e jogos de vôlei de rua. A pesquisa se classificou como qualitativa, descritiva, tendo entrevistas como técnica de coleta de dados.

O artigo estruturou-se nas seguintes partes: A primeira é a introdução, na qual fez uma apresentação do tema, objetivos, questões da pesquisa e dos procedimentos metodológicos; A segunda parte do artigo apresentou o percurso metodológico seguido na investigação; A terceira parte abordou as perspectivas teóricas que definem o percurso analítico através de uma breve síntese para conceituar cultura e mediação cultural (TYLOR, 1871; GEERTZ, 1973; BOAS, 2004; LARAIA, 1986; LAMIZET, 1999; BARBERO, 2009, 1997, 1995) e os conceitos de campo e habitus de Pierre Bourdieu (1983, 1992, 1996a, 1996b, 2004a, 2004b, 2011); A quarta parte tratou do vôlei de rua em Cuiabá, apresentando aspectos da origem desta modalidade esportiva; A quinta parte trouxe análise das entrevistas acerca do tema investigado; A sexta parte 
apresentou as considerações finais uma síntese dos achados e das conclusões da investigação.

\section{Percurso Metodológico}

Trata-se de uma pesquisa qualitativa, do tipo descritiva. A mesma pautou-se em relatos conhecidos como histórias de vida dos seus agentes, um estudo sobre a vida de um indivíduo ou grupo de indivíduos, onde são incluídos os relatos, documentos possíveis tais como fotos, recortes de jornais, postagens em sites e redes sociais, utilizamos ainda termo de consentimento livre e esclarecido, roteiro de entrevistas e caderno de observação. Foram realizadas 14 entrevistas com praticantes e amantes do vôlei de rua no ano de 2017 em Cuiabá/MT.

A história de vida ou história oral possibilitou a essência subjetiva da vida de uma pessoa surja, através dos relatos em primeira pessoa sobre a trajetória no âmbito das relações humanas, sendo uma maneira que aproximou pesquisadores e agentes sociais, dando-lhes papel ativo, sobretudo ao segundo que reflete sobre sua própria vida.

O termo história oral é também utilizado para denominar relatos que registram a experiência de um ou mais indivíduos de um grupo social (QUEIROZ, 1988). Em vez de enfocar os indivíduos que fornecem os dados, destacar processos, eventos, causas, efeitos, normalmente fornecendo dados para histórias de vida.

É importante lembrar a existência de ampla categoria de expressões relacionados/sinônimos de história de vida, tais como autobiografia, biografia, narrativa de história de vida, narrativa oral, narrativa de vida, entre outras, largamente utilizadas em estudos de antropologia, sociologia, psicologia, história, medicina, ciência política, literatura, entre outras (HATCH; WISNIEWSKI, 1995). 
Neste estudo, entendemos história de vida como uma estratégia de pesquisa que busca captar a vivência e o significado do vôlei de rua nas narrativas pessoais envolvidas com este esporte, e partes significativas de uma vida ou de toda uma vida coletadas por meio de conversas ou entrevistas (DENZIN, 1989).

As entrevistas foram realizadas com jogadores (praticantes), organizadores, mídia local e espectadores. O critério para escolha dos entrevistados ocorreu através da acessibilidade, disponibilidade e o desejo de contribuir com a pesquisa. Nas entrevistas semiestruturadas com perguntas abertas, em forma de relatos, as indagações foram feitas de maneira não padronizada, sendo mais espontâneas. Os relatos foram agrupados em categorias de abordagem, cada qual trazendo uma temática distinta. Foram realizadas um total de 14 entrevistas, para esta análise trouxemos para o artigo somente cinco entrevistados os que mais se destacaram em nossa pesquisa.

\section{Referencial Teórico}

\section{Cultura e Mediação Cultural}

O termo cultura (do latim colere) que significa cultivar é um conceito de várias acepções, sendo que neste estudo trouxemos as teorias originais defendidas por Tylor, Boas e Geertz respectivamente.

Tylor (1871) definiu Cultura como a expressão da totalidade da vida social do homem, caracterizada pela sua dimensão coletiva; este autor formalizou uma ideia que vinha sendo desenvolvida desde o Iluminismo, segundo a qual: "cultura é o todo complexo que inclui conhecimentos, crenças, arte, moral, leis, costumes ou qualquer outra capacidade ou hábitos adquiridos pelo homem enquanto membro de uma sociedade” (TYLOR, 1871, apud VELHO e VIVEIROS DE CASTRO, 1980, p. 39). 
Já a concepção de Cultura de Franz Boas (2004) se contrapunha ao pensamento evolucionista, acreditava na autonomia das Culturas (relativismo cultural) e que cada cultura possuía uma particularidade. Segundo ele, a cultura se manifesta pelos costumes. Em sua obra Antropologia Cultural, Boas (2004) conceituou cultura como configuração única e construída entre o local de sua diversidade e o desejo de compreensão de projeção e interesse das ciências de sua universalização.

Segundo Geertz, “a cultura não é um poder, algo ao qual podem ser atribuídos casualmente os acontecimentos sociais, os comportamentos, as instituições ou os processos; ela é um contexto, algo dentro do qual eles (os símbolos) podem ser descritos de forma inteligível - isto é, descritos com densidade" (GEERTZ, 1973, p. 24).

Nosso entendimento neste trabalho consistiu em considerar as mediações sobre o olhar da cultura, evidenciando os significados, signo e símbolos. Por isso, adotamos a perspectiva defendida por Geertz, em que a "cultura deve ser considerada não um complexo de comportamentos concretos, mas um conjunto de mecanismos de controle (...)" para governar o comportamento. Geertz afirma ainda, que "todos os homens são geneticamente aptos para receber um programa, e este programa é o que chamamos de cultura" (LARAIA, 1986, p. 62). Acreditando, como Max Weber, que o homem é um animal amarrado a teias de significados que ele mesmo teceu, assumiu a cultura como sendo essas teias e sua análise; portanto, não como uma ciência experimental em busca de leis, mas como uma ciência interpretativa, à procura do significado. (GEERTZ, 1973, p. 15).

Cultura, portanto, pode ser entendida como um campo de luta pelas representações, nos quais diferentes grupos culturais situados em posições antagônicas confrontam-se em busca das imposições de seus significados, a cultura imbrica-se com 
as relações de poder existentes a partir do contato entre uma ou mais culturas. $\mathrm{O}$ vôlei de rua constituiu-se como um elemento da cultura contemporânea.

Ao adotarmos os aspectos das mediações culturais do vôlei de rua como objeto de análise, se fez necessário conceituar o termo "mediador". O termo mediar tem vários significados, que passam pelo jurídico mediador de conflitos até o acadêmico mediador de mesas redondas.

É mediador, em um território "de práticas sociais que se desenvolvem em domínios institucionais diferentes e que visam construir um espaço determinado e legitimado pelas relações que se manifestam", de acordo com Caune (1999, p. 20).

Em francês Mèdiation culturelle, significa o coletivo de pessoas pelas quais os objetos ou obras poderiam se tornar conhecidos, descobertos, compreendidos, de maneira que os mediadores interajam da circulação de informações do sistema cultural. Assim sendo, podemos considerar "que a cultura se dá visível pela mediação" (LAMIZET, 1999, p. 15).

As mediações passam a ser transformação do tempo e do espaço a partir de dois grandes eixos, migrações e fluxos de imagens e, como consequência, as duas mediações fundamentais para pensar o processo de mutação cultural são, para ele, a identidade e a tecnicidade (BARBERO, 2009, p. 14).

O autor propõe que as mediações fossem transformadas em dimensões: identidade e tecnicidade. A identidade relaciona-se com a interação social preconizando as negociações do indivíduo com o poder e com as instituições. E a tecnicidade remete a construção de outras práticas da lógica de produção por meio das diferentes linguagens do meio. 
A concepção Barberiana de mediação passou a adotar o simbólico como expressão do meio. Assim, “o eixo do debate deve se deslocar dos meios para as mediações, isto é, para as articulações entre práticas de comunicação e movimentos sociais, para as diferentes temporalidades e para a pluralidade de matrizes culturais" (BARBERO, 1995, p. 55).

Assim, o vôlei de rua e suas diferentes linguagens, construíram uma ação mediadora com suas estratégias de acesso e aproximação, especialmente da cultura contemporânea em seus processos de interatividade, entre os praticantes, organizadores e o público em geral, essas ações são notoriamente processos culturais que analisamos na presente pesquisa.

O "vôlei de rua" torna-se um mundo à parte que, num vai nem vem de simbolismo, também possui suas regras e normas, ora se aproximando das leis funcionais do cotidiano, ora criando seus próprios códigos. Esta modalidade esportiva aqui foi entendida como elemento do lazer. O esporte de lazer pode ser caracterizado pelo não profissionalismo e tem como qualidades principais a busca por prazer e socialização, compensação, recuperação ou manutenção da saúde, equilíbrio psicofísico, restauração e relaxamento (STIGGER, 2002).

\section{Campo e Habitus}

Os conceitos fundamentais dos quais fizemos uso, na análise aqui empreendida, da teoria de Bourdieu foram basicamente os de campo e habitus.

A proposta sociológica de Pierre Bourdieu (2011; 2003; 1996a; 1992) nos possibilitou refletir sobre a produção do corpo com base na história incorporada pelas disposições. A categoria habitus é capital nesse empreendimento, pois nos permitiu 
entender a corporificação da história, ou seja, a internalização desta nos corpos dos indivíduos. Por meio do conceito de habitus, Bourdieu $(1983 ; 1992 ; 1996 a)$ trata do papel do corpo no processo de socialização do sujeito, preocupado em entender como as estruturas sociais, dentro de determinadas condições sociais e históricas específicas, moldam o corpo do indivíduo, escrevendo-lhes valores, significados e regras de conduta.

O esporte ocupa um importante lugar na sociedade moderna, seja na estruturação dos espaços e posições sociais, seja na construção dos corpos. Nesse sentido, o fenômeno esportivo também é um mecanismo/elemento que nos possibilita perceber e analisar a construção do habitus. $\mathrm{O}$ esporte pode também ser visto como um campo específico da vida social moderna. Trata-se de um espaço social relativamente autônomo, com regras de funcionamento, tendo atores sociais interessados em definir essas regras e os valores dominantes.

Segundo Bourdieu, o "campo, no seu conjunto, define-se como um sistema de desvio de níveis diferentes e nada, nem nas instituições ou nos agentes, nem nos actos ou nos discursos que eles produzem, têm sentido senão relacionalmente, por meio do jogo das oposições e das distinções" (BOURDIEU, 2003, p. 179).

Consideramos que pensar a partir do conceito de campo é pensar de forma relacional. Trata-se de adotar uma postura epistemológica de conceber o objeto estudado em constante relação e movimento. Neste sentido, o conceito de campo é oportuno pois pressupõe confronto, luta, disputa, tensão, poder, já que, pois, “é um campo de forças e um campo de lutas para conservar ou transformar esse campo de forças” (BOURDIEU, 2004a, p. 22-23). 
A proposta aqui é pensar o vôlei de rua como parte de um campo maior, a saber, o campo esportivo. Os campos são formados por agentes (indivíduos ou instituições), os quais instituem os espaços e os fazem permanecer pelas relações que aí estabelecem. As disputas e estratégias na organização dos torneios e eventos do vôlei de rua em Cuiabá constituem um campo social específico carregado de interesses, intenções e normas de funcionamento. Cabe frisar que os agentes envolvidos nos esportes incorporam determinados habitus. No caso específico do vôlei de rua, existe um habitus típico deste esporte.

O habitus é o sistema de posições e disposições incorporado nos indivíduos ao longo de sua história de vida. Nas palavras do autor:

O habitus, sistema de disposições adquiridas pela aprendizagem implícita ou explícita que funciona como um sistema de esquemas geradores, é gerador de estratégias que podem ser objetivamente afins aos interesses objetivos de seus autores sem terem sido expressamente concebidos para esse fim. Há toda uma reeducação a ser feita para escapar à alternativa entre finalismo ingênuo [...] e a explicação do tipo mecanicista (que tornaria esta transformação por um efeito direto e simples de determinações sociais). Quando basta deixar o habitus funcionar para obedecer à necessidade imanente do campo, e satisfazer às exigências inscritas (o que em todo campo constitui a própria definição de excelência, sem que as pessoas tenham absolutamente consciência de estarem se sacrificando por um dever e menos ainda o de procurarem a maximização do lucro específico). Eles têm assim, o lucro suplementar de se verem e serem vistos como perfeitamente desinteressados (BOURDIEU, 1983, p. 94).

O próximo item trata do vôlei de rua em Cuiabá/MT, quando apresentaremos os resultados e a análise da pesquisa de campo. 


\section{O Vôlei de Rua em Cuiabá/MT: Origem e Desenvolvimento}

\section{O Voleibol de Rua}

Neste tópico apresentaremos brevemente o contexto do advento do vôlei de rua em Cuiabá.

O surgimento do "vôlei de rua" é tão antigo quanto à modalidade competitiva do voleibol de quadra; principalmente no Brasil a prática do vôlei de rua é um acontecimento da infância e das brincadeiras que ocorriam nas "ruas" como forma de lazer.

Antes de quaisquer pretensões definidoras, em Programa para uma sociologia do esporte, Bourdieu (2004b) atenta sobre o trabalho do pesquisador, que reside em construir primeiramente a estrutura do espaço das práticas esportivas, para que se vejam seus efeitos. Também, que o dito espaço não se fecha sobre si mesmo, contrariamente se insere num universo de práticas e consumos que formam um sistema. Assim, buscaremos construir uma descrição do conjunto do espaço e território "vôlei de rua", lançando mão dessas ramificações que o constituem espetacular e lúdico.

Espaço, segundo Bourdieu (1996b, p. 24), é um “conjunto de posições distintas e coexistentes, exteriores umas às outras, definidas umas em relação às outras por sua exterioridade mútua e por relações de proximidades, de vizinhança ou de distanciamento e, também, por relações de ordem, como acima, abaixo e entre". O espaço social organiza-se e estrutura-se de acordo com a quantidade e com os tipos de capital que os agentes ou grupos sociais possuem. Pode-se dizer que os diferentes capitais são distribuídos em uma primeira coordenada pelo volume do capital global que possuem e em uma segunda coordenada pela composição deste capital global. 
O espaço se apresenta como um conjunto indivisível de sistemas de objetos e sistemas de ações, os quais nunca podem ser considerados de forma isolada. Deve, portanto, ser visto como um quadro único de análise no qual se produz a ação histórica. As relações sociais produzem espaços conflituosos ao se apresentarem como geradora de espaços fragmentados, dicotomizados ou fraccionados.

É crucial aqui a noção de campo. Este é entendido como um espaço de luta e disputas pela posse sobre um determinado capital e sobre o poder de impor os princípios de visão e de divisão. Os agentes sociais participam de diversos campos: campo econômico, escolar, jurídico, político, artístico e possuem determinadas quantidades de capitais relativos a cada dos campos.

Nessa concepção, o "vôlei de rua" é o espaço de sociabilidade e lazer das camadas populares, sendo às vezes única opção de ocupação territorial e temporal que muitas pessoas acedem.

O "vôlei de rua" é simultaneamente um evento de massa e espaço de lazer, de recreação. Contudo, o espaço não se fecha sobre si mesmo; contrariamente, se insere em um campo popular de suas práticas e consumos que formam um sistema. A rua se torna para muitos um espaço de poder e de manifestação cultural em torno do esporte. De tal modo, descreveremos neste espaço um conjunto singular do "vôlei de rua", abrindo mão dos aspectos que constituem caracteres do espetáculo e lúdico.

As comparações entre o vôlei de rua e o voleibol de quadra são inevitáveis. Os praticantes do vôlei de rua (amador) da cidade de Cuiabá, por exemplo, começaram a fazer comparações entre o jogar na rua e o jogar na quadra, do que é real e o que é do imaginário, dos praticantes da rua. O "vôlei de rua" apresenta uma estética muito particular, própria daquele espaço, a rua faz referência e representa a quadra de voleibol 
tradicional. Ao contrário da quadra as regras, a criatividade e a estrutura do vôlei de rua fazem desta uma prática informal da contemporaneidade, considerando o conceito sobre ludicidade e identificando a atividade lúdica no jogo, no brinquedo e na brincadeira, levando em consideração o prazer e não o caráter competitivo e mecânico. A manifestação é qualificada pela alegria, pelo prazer de sua vivência, pelo descompromisso e pela negação aos critérios competitivos de suas regras impostas.

Portanto, o espaço do esporte aparentemente favorável, que propõem uma relação espacial distinta é um lugar de práticas possíveis; a oferta, e um espaço das disposições a serem praticadas, a procura, de espaço de poder.

Do lado da oferta, temos um espaço dos esportes entendidos como programas de práticas esportivas, que são caracterizadas, em primeiro lugar, em suas propriedades intrínsecas, técnicas (isto é, em particular, as possibilidades e sobretudo as impossibilidades que eles oferecem à expressão das diferentes disposições corporais), e, em segundo lugar, nas suas propriedades relacionais, estruturais, tal como se definem em relação ao conjunto dos outros programas de práticas esportivas simultaneamente oferecidas, mas que só se realiza plenamente num dado momento, recebendo as propriedades de apropriação que sua associação dominante lhes confere, tanto na realidade como na representação, através dos participantes modais, em relação a uma posição no espaço social; por outro lado, da parte da procura, temos um espaço das disposições esportivas que, enquanto dimensão do sistema de disposições (do habitus), estão relacionamento, estruturalmente, caracterizadas como as posições às quais elas correspondem, e que num dado momento são definidas na particularidade de sua especificação pelo estado atual da oferta (que contribui para produzir a necessidade, apresentando-lhe a possibilidade efetiva de sua realização) e também pela realização da oferta no estado anterior (BOURDIEU, 2004b, p. 214).

Podemos sinalizar que o pensamento de Bourdieu se direciona na tentativa de compreender a sociedade - não no sentido de sua totalidade, mas a partir de seus campos sociais que, segundo o intelectual francês, se caracterizam pela autonomia relativa e pelas relações específicas de interdependência, sob uma ótica relacional. Desde então, sua perspectiva sociológica focaliza as ações individuais coordenadas e se distancia de 
abordagens que veem o indivíduo com pouca importância analítica ou o classificam osocial, isolado ou agente de si mesmo.

Destaca-se, ainda, que o campo esportivo possui sua autonomia relativa e não pode ser somente relacionado ou articulado com condições sociais, políticas e econômicas de dada sociedade ou contexto social. Sendo assim, defende-se que o estudo do fenômeno esportivo é mais amplo, já que possui autonomia, regras próprias, crises, etapas e cronologias.

O campo possui regras próprias de funcionamento e conta com diversos praticantes sociais com interesses distintos. No caso do esporte, são os atletas, dirigentes, torcedores e jornalistas, entre outros, que podem ser considerados atores.

Considerando a história do vôlei de rua em Cuiabá, podemos destacar alguns acontecimentos relatados pelos agentes praticantes da modalidade desde sua primeira etapa. A prática e a organização do vôlei de rua atual ganharam destaque em duas localidades distintas da região metropolitana de Cuiabá. Segundo o primeiro relato, onde ocorreram as primeiras brincadeiras de vôlei de rua e as primeiras etapas organizadas desta modalidade foram no bairro Tijucal, na região Sul da capital e na cidade de Várzea Grande/MT, que localiza - se na região Norte da capital.

Na década de 1990, os primeiros grupos de amigos e jogadores de voleibol de quadra, encontravam se para dividirem experiências e técnicas da modalidade, em um contexto informal e descontraído, a rua. Nestas duas regiões, o vôlei de rua acontecia no contraturno das atividades regulares de seus praticantes como, por exemplo, após a o período escolar (período de aulas) e os treinamentos desportivos de quadra. No bairro Tijucal, as manifestações esportivas como o vôlei de rua aconteciam na praça do Popeye, muito conhecida e frequentada até os dias atuais pelos moradores do bairro, 
hoje não mais com atividades esportivas, mas com entretenimento, como playground, culinária e bares (LIMA, 2018).

Conforme relatos de alguns entrevistados, a descrição sobre o ambiente no bairro Tijucal era o ponto de encontro de grandes atletas de voleibol de quadra da época no estado e os apreciadores desta modalidade, que se reuniam para disputas na rua, em jogos de um set corrido (set é o conjunto de pontos; neste caso do vôlei de rua é de 15 pontos, como na época era o tiebreak, significa o set desempate de uma partida de voleibol de quadra), jogavam em times de trios (três jogadores por equipe, um levantador e dois atacantes).

A estrutura da quadra também é modificada conforme a rua, o tamanho varia entre 18 metros de comprimento por 9 metros de largura e 15 metros de comprimento por 7 metros de largura.

A rede que divide uma equipe da outra tem a altura aproximadamente de 2,43 metros de altura, a mesma altura do voleibol de quadra, categoria masculina. Algumas regras sugeridas eram retiradas dos jogos oficiais de quadra. Qualquer jogador que estiver na rede não poderá encostar na rede em nenhuma de suas partes.

Na rua não existe a linha de 3 metros, portanto qualquer jogador pode atacar na rede; não pode haver nenhum tipo de invasão por cima nem por baixo e o rodizio acontece sequencialmente. As regras nunca tinham um padrão único, elas seguiam o contexto do grupo que ali participavam naquele dia.

Na cidade de Várzea Grande, no bairro Jardim dos Estados e no Ipase, na região Norte da cidade, ocorriam partidas quase simultaneamente com grupos distintos e, muitas vezes, nos fins de semanas os grupos se encontravam para uma grande manifestação esportiva e para as interações sociais. Os atletas que naquele momento já 
não jogavam mais em quadra e atletas de voleibol atuantes que frequentavam estes locais jogavam informalmente e o jogo na rua era considerado uma diversão (LIMA, 2018).

Dentre os vários personagens e atletas, o protagonista desta história nunca foi um grande jogador, um levantador, até pela sua altura que era entre 1,60 metros a 1,68 metros, o senhor Délio Lima, foi o grande idealizador do vôlei de rua em Cuiabá e no estado de Mato Grosso, criador da AEVR - Associação Estadual de Vôlei de Rua. Délio Lima nasceu no Estado de Mato Grosso em meados da década de 1970. Conforme relatos de alguns agentes e amigos do Délio Lima, ele foi usuário de drogas, e passou por todos os tipos de problemas que permeiam as pessoas nesta situação vulnerável. Ele era um cara de um metro e meio de altura que se intitulava como um bom levantador de voleibol, no meio do caminho ele teve um grave acidente de moto, no qual quase teve que amputar um dos pés, e superou todas essas dificuldades com a parceria de alguns amigos. Sempre foi uma pessoa que todos o admiravam pela força de vontade e por ter conseguido aglutinar tantas pessoas em um projeto de vôlei de rua (idealizado pelo Délio Lima e com o João - Papaguaio).

A prática do "vôlei de rua" foi estruturada pelos seus praticantes, muitos exjogadores de voleibol de quadra amador, de vôlei de areia e até mesmo ex-jogadores profissionais de voleibol de quadra. $\mathrm{O}$ vôlei de rua teve seu início neste formato em Cuiabá/MT, no ano de 2010, com a dedicação e atuação, portanto, do Presidente da Associação Estadual de "Vôlei de Rua", o Sr. Délio Lima, que idealizou o Circuito Estadual de "Vôlei de Rua", o qual atendia a capital e alguns municípios da baixada cuiabana, com 7 e 8 etapas por ano em diversos bairros e cidades da baixada cuiabana do Estado de Mato Grosso. 
Em março de 2010 foi veiculado nas mídias sociais a divulgação do primeiro circuito estadual de vôlei de rua, que aconteceu em Cuiabá/MT. Esta etapa ocorreu no $1^{\circ}$ domingo do mês de março do mesmo ano, com a intenção de mobilizar a comunidade cuiabana para mais uma forma de lazer, principalmente esta, tão praticada nas escolas e clubes da nossa capital. A importância das mídias sociais neste processo foi muito grande, pois colocou em evidência as características, data, local e premiação; esta etapa, em específico, contou com a participação de 16 trios somente na categoria masculina, e foram divididos em 4 chave de 4 trios cada uma. $\mathrm{O}$ valor cobrado das inscrições foi considerável (60 reais por trio), pois pensaram nos custos que o evento teria: premiação, arbitragem, estrutura, água e despesas extras. O total da arrecadação para esta específica etapa foi de 960 reais, computando os gastos com: Arbitragem (300 reais, divididos em: $1^{\circ}$ arbitro, $2^{\circ}$ arbitro e a mesa), os 160 reais foram usados para de custear água para todos os participantes diretos, pintar as linhas que delimitaram a quadra de vôlei de rua e 500 reais utilizados na premiação (LIMA, 2018).

Com poucos recursos e muita vontade a $1^{\text {a }}$ Etapa da Associação Estadual de Vôlei de Rua, ocorreu no Bairro Tijucal, ao lado da Praça do Popeye. Depois de muitos anos que aconteceu a primeira etapa no bairro: Tijucal na capital Cuiabá, volta para o mesmo bairro outra etapa, mas desta vez com a estrutura da organização da Associação Estadual de Vôlei de Rua.

Na etapa do bairro: Tijucal, há um sentimento histórico, pois aqui foi onde tudo começou, portanto, retornar ao passado desperta um sentimento de lembranças e relembrar como era e como esta as etapas. Depois de $10^{\text {a }}$ etapa ela retorna para suas raízes. 
Com o sucesso da primeira etapa do vôlei de rua, os idealizadores Délio Lima e o João (Papaguaio), decidiram investir, com maior ênfase neste formato de torneio. A princípio as etapas aconteciam somente nos bairros de Cuiabá e no município de Várzea Grande; com o crescimento e a vinda de atletas de outros municípios do estado do Mato Grasso e até de fora do estado, a Associação Estadual de Vôlei de Rua, passou a migrar suas etapas para os municípios em datas como no aniversário da cidade, festivais de pesca e nos feriados prolongados.

As etapas de vôlei de rua foram acontecendo, ano a ano, mês a mês, houve etapas que foram realizadas em cidades como em Barão de Melgaço/MT, baixada cuiabana, fica localizada a $64 \mathrm{~km}$ da capital Cuiabá/MT.

Segundo Lima (2018), dentre outras, na cidade de Várzea Grande/MT teve muitos trios inscritos, nesta trajetória aconteceu mais duas etapas a $2^{\mathrm{a}}$ e a $7^{\mathrm{a}}$, que podemos destacar, por conta da localidade, o fácil acesso ao público que gostam este esporte contemporâneo, a cada etapa os relatos das melhorias em estrutura, planejamento e investimentos eram compartilhado pelos atletas, organizadores e participantes, entretanto, foi interesse investigar as mediações que permeiam nestes espaços, com tudo o objetivo geral deste estudo foi investigar as mediações e conflitos que se relacionavam entre seus agentes na prática do vôlei de rua.

No próximo item apresentaremos a análise das entrevistas realizadas na pesquisa de campo. 


\section{Análises das Entrevistas com Praticantes do Vôlei de Rua}

\section{O Perfil dos Praticantes de Vôlei de Rua}

Nas primeiras narrativas apresentadas, acerca do perfil dos entrevistados, encontramos um público distinto com interesses comuns à paixão e ao prazer de jogarem e estarem envolvidos com o vôlei de rua. O esporte como mediador cultural desta prática, remetem diretamente às narrativas expostas e discutidas aqui.

Buscamos identificar o perfil do jogador da modalidade vôlei de rua; considerando o a idade, sexo e profissão e desvendar que mesmo em um grupo eclético, eles se reconhecem/identificam na prática do vôlei de rua.

1. Tenho 42 anos, sou católico, bancário tenho uma vida estável (Narrador 1).

2. Fiz 18 anos este ano, não pratico religião alguma, sou estudante e vivo com os meus pais (Narrador 3).

3. [...] desde os [...] os 16 anos. Os 12 que foi brincadeira depois com os 16 anos eu fui para quadra, eu parei com 22 quando eu casei. Voltei, retomei depois com 32,34 senão me falha a memória e então eu voltei a jogar e isso tem mais de $60 \%$ do meu tempo de vida eu pratico vôlei e eu estou muito feliz. Muito bem, obrigado, como diz o velho ditado, praticando voleibol. Eu acho que é muito interessante. Meu sonho é de praticar ele se deus, o grande arquiteto do universo me deixar praticar ele até os 80 , entendeu (Narrador 2).

4. Eu na verdade comecei a jogar assim...eu era de outro esporte. Comecei a jogar no voleibol e dezoitos anos já, lá em 1998 (Narrador $4)$.

5. Me chamo Everton. Apelido boi. Boi porque quando ele sai daqui com 14 anos para jogar no Minas, o pessoal pegava muito no meu pé, porque era de Mato Grosso. Então eles ligavam uma coisa com outra, Boi, Mato Grosso, e ficou esse apelido (Narrador 5).

Os relatos mostram que temos jogadores de diversas idades e profissões, mas o fenômeno social "esporte" neste específico caso, é o vôlei de rua, que faz a inter-relação social entres seus pares. O que nos chama bastante atenção é o nível esportivo de cada um dos jogadores como descreve o narrador 3: tem apenas 18 anos é estudante e 
jogador de voleibol iniciante, em contrapartida, o narrador 1, tem 42 anos, profissão consolidada e também é um jogador de voleibol das antigas, estes dois extremos analisados nesta pesquisa foram de extrema importância para a consolidação deste estudo, pois este grupo se encontram em uma "rua" para dividir o mesmo espaço de disputa, em jogos de vôlei de rua (LIMA, 2018).

Verificamos que há um público diversificado no que diz respeito à idade, valores morais e religiosos dos entrevistados, o que permite a emergência de elementos favoráveis às diversas mediações culturais.

O narrador 5 aponta as dificuldades enfrentadas e as estratégias adotadas no início da modalidade do vôlei de rua em Mato Grosso. Destaca a ausência de times e os arranjos sociais para formação das equipes nos primeiros torneios e etapas desta modalidade esportiva.

[...] "eu pratico voleibol há 7 anos, o vôlei de rua é minha primeira vez, eu fui convidado por um ex técnico meu, para vir nesta etapa, mas nunca tinha jogado vôlei de rua. Minha maior paixão é o vôlei de quadra, e o de rua tem tudo a ver, senti um pouco de dificuldades para me adaptar na rua. Tudo é diferente jogamos somente com três jogadores, as regras mudam, o lugar e diferente hoje jogamos com chuva e vento, o que eu mais senti de diferente da quadra foi a pontuação, na quadra você tem um tempo para recuperar a partida que é de no mínimo 3 sets, na rua não é somente 1 set de 25 pontos, mata" (Narrador 3).

Conforme o narrador 3 , ele teve sua primeira experiência na rua, e como podemos observar ele revela as principais diferenças entre jogar na quadra e na rua, a adaptação, na quadra são seis jogadores enquanto na rua são somente três, as regras são reconfiguradas para rua, o ambiente é cambiante. Nesta etapa ele revela que jogaram com chuva e muito vento, dificultando assim, sua performance em jogo. A pontuação também foi algo que o narrador 3 explanou, na rua os jogadores só têm 21 ou 25 pontos dependendo da etapa, para recuperar o jogo; em contrapartida na quadra os jogadores 
têm três sets para de 25 pontos para recuperar o jogo, descrevendo o termo "matamata", perdeu o jogo, automaticamente o time ficará fora de uma disputa pelas finais.

Nossa nem me lembro há quanto tempo eu jogo voleibol, o de quadra, mas deixa eu ver, jogo voleibol a exatamente 31 anos, na rua estou jogando a mais ou menos 5 anos, fui convidado a participar das primeiras etapas de vôlei de rua que acontecia em Cuiabá, pelo próprio Délio, ele era meu grande amigo, no início senti algumas dificuldades em jogar na rua, pois na rua jogamos em trio e a responsabilidade é muito maior. Senti muita dificuldade na rua por conta das dimensões da quadra, mas por outro lado o clima o ambiente as pessoas os amigos, nossa isso faz toda diferença (Narrador 1).

\section{Diferenças entre o Vôlei de Rua e o Vôlei de Quadra}

De conduta estruturada, o vôlei de rua, através da fala do narrador 1 , revela a experiência deste jogador enquanto atleta de voleibol de quadra. Desde a formação estruturada e organizada pelo Délio Lima, ele já faz parte desta modalidade tão antiga e contemporânea ao mesmo tempo. Como no início de qualquer modalidade a adaptação foi complexa, entendendo que conforme sua fala a responsabilidade de jogar em trios é muito maior do que jogar na quadra com 6 jogadores, e é difícil habituar-se com as dimensões da quadra na rua. Contudo, o clima das relações com os amigos, fez toda a diferença entre ficar em casa e sentir o tempo passar ou vir para a rua, reviver o esporte e reencontrar antigas amizades.

\footnotetext{
Ah! É completamente diferente. Sofre bastante porque as medidas são completamente diferentes. A rede está um pouco mais baixa. $\mathrm{O}$ voleibol de rua... Ele quem pratica leva muita vantagem sobre o jogador de quadra. Então, é completamente diferente, eu sofro bastante para jogar aqui (Narrador 2).
}

No trecho acima, o narrador 2, desenha uma realidade constante que acontece com jogadores que nunca jogaram vôlei de rua, são muitas diferenças encontradas, mesmo tendo o mesmo nome da modalidade oficial, no ambiente externo e peculiar a 
rua se transforma em uma arena de disputa, e o prêmio em questão é o domínio pela rua.

Quem é o rei da rua? Geralmente não é o mesmo que o maior pontuador das quadras!

Segundo o narrador 2, quem dominar a modalidade de rua, certamente leva vantagem na quadra.

O vôlei de quadra ele tem uma denotação da marcação, o tamanho, a espessura, o tamanho da quadra, né. Ela é um pouco maior, né. Até porque jogam mais atletas, são seis atletas no ... vôlei de quadra e ... no vôlei de rua são três, geralmente é trio, né. Inclusive, nós até fizemos algumas sugestões outras vezes, prá ser de quarteto, mas fica pequeno a rua, já não fica tão legal. Então essa é uma das diferenças. Existem outras diferenças na marcação, né. A lei que faz na hora ali, a regra que é acordado antes de acontecer a brincadeira ou até mesmo no torneio, é acordado ali, não pode conduzir a bola de uma maneira que lá no jogo, na quadra é diferente, né. Igual no vôlei de... areia, por exemplo, a maneira de você levantar é diferente, você não pode tocar de mão aberta, você tem de fechar a mão prá tocar na bola, senão é condução. Então, são algumas dessas é ... regras que são diferentes também no vôlei de rua, né. Ali você a ... marcação é um meio fio, lá na quadra é a linha pintada, né. Então tem algumas diferenças assim no vôlei de quadra (Narrador 5).

O número de atletas, o tamanho e a espessura da marcação da quadra são diferenças entre as modalidades de vôlei de rua e de quadra, conforme falas dos entrevistados.

\section{O Entorno dos Eventos do Vôlei de Rua: Sociabilidades e Disputas}

Uma pergunta feita aos atletas, refere-se aos participantes (são aqueles que participam das etapas, mas não treinam e nem foram jogadores de quadra); algumas vezes os participantes são ex-atletas de outras modalidades, jogadores e atletas (estes são aqueles que mesmo no voleibol de quadra ou no vôlei de rua, são atletas no seu dia a dia, são ex-jogadores profissionais de voleibol de quadra, de vôlei de areia) do vôlei de rua, foi-lhes questionado que: Em sua opinião, além do jogo, o que você pode apontar que acontece como um todo nos eventos de vôlei de rua? 
[...] estou impressionado quanta informação estamos tendo na rua as pessoas são tão interativas, ajudam a catar a bola, os vizinhos levam água e até outras bebidas, as ligações que podemos perceber dos vizinhos nossos amigos e família com o vôlei de rua é muito legal, isso faz com que podemos jogar e estar entre amigos e família (Narrador 2).

Quando destacamos a impressão que os participantes, jogadores e atletas tem sobre o que acontece no entorno de onde ocorre as etapas de vôlei de rua, nos surpreendemos com alguns relatos citados aqui, como por exemplo o narrador 2, que diz “sentir-se muito confortável com a acolhida principalmente dos vizinhos que primeiramente saem das casas para ver o que está acontecendo, posteriormente se unem ao grupo, ora como espectador ora como ajudantes, pegam as bolas, servem água e outras bebidas. O clima é familiar e convidativo.

[...] eu acho muito interessante por que aqui na rua eu sou o rei dela, enquanto na quadra eu não tinha o mesmo prestígio, adoro isso (Narrador 4).

A disputa por poder na sociedade acontece ao longo da evolução da humanidade; no esporte e principalmente no vôlei de rua não seria diferente, mais latente que em jogo de voleibol de quadra, as provocações em um jogo de vôlei de rua, são muito maiores, pois as relações de amizade e as relações de tempo no esporte, fazem com que cada um já conheça os pontos fortes e os pontos fracos, independente se dentro ou fora do jogo de vôlei de rua; para o narrador 4, ele se intitula como o "rei da rua", e isso que o motiva, mas tem a consciência de que se estivesse em outro contexto (o voleibol de quadra, por exemplo), não teria a mesma notoriedade. Como explica Bourdieu (1983, p. 90):

Para que um campo funcione, é preciso que haja objetos de disputas e pessoas prontas para disputar o jogo, dotadas de habitus que impliquem no conhecimento e no reconhecimento das leis imanentes do jogo, dos objetos de disputas, etc. (BOURDIEU, 1983, p. 90). 
O poder mais importante, na disputa do campo (rua) no esporte vôlei de rua, seduz e interliga os participantes, jogadores e atletas, dentro do campo específico em suas regras e coerências. Para estarem inseridos no jogo seus participantes, jogadores e atletas do vôlei de rua, existem obrigações de dividir comportamentos e atitudes do próprio jogo. O campo social neste caso a "rua", é um espaço correspondente e frequentado pelos agentes pertencentes a ele e que possuem particularidades e consentimentos às regras determinantes que determinam este meio (LIMA, 2018).

Os jogadores compartilham habitus. Segundo Bourdieu (2011), habitus é a condição condicionante do campo, os participantes, jogador e atleta que não tem as particularidades ou não consegue habituar-se ao habitus para a convivência em grupo será excluído do campo por não fazer parte do meio. "O habitus é essa espécie de senso prático do que se deve fazer em dada situação- o que chamamos, no esporte, o senso do jogo (...)" (BOURDIEU, 2011, p.42).

Olha, primeiramente eu vim aqui para...mais... é pra mim tá me exercitando, entendeu. Porque hoje em dia, se você fica parado é perigoso você ter um $\mathrm{AVC}$, entendeu. Então se você está praticando um esporte... qualquer esporte (Narrador 1).

Percebemos que os agentes praticantes do vôlei de rua conseguem ter sentimentos diferentes com fazeres comuns ao jogo, onde a percepção de um não se reflete no outro, essa bifurcação se media no mesmo ambiente com interesses distintos ou conflituosos. Essa talvez seja uma das mais impressionantes facetas do vôlei de rua. Conforme referência o narrador 1, o mais importante é participar de alguma atividade esportiva, almejando uma vida saudável.

A análise dos relatos nos permite identificar quanto a mediações culturais entre os agentes participantes do vôlei de rua, segundo Barbeiro (1997), que o massivo não anula o popular na produção da cultural. Ao contrário, elementos da dimensão popular 
como o vôlei de rua, conseguem se infiltrar no massivo, mantendo sua tradição e cultura, o que leva à constituição de uma mistura cultural, com valores, crenças e formatos que, não raro, se opõem.

Conforme o mesmo autor, a partir daí, enfatiza as inter-relações que tecem emissores e receptores e os fatores intervenientes nessa relação, bem como nas formas de apropriação e (re) significação de sentidos que frequentam a pluralidade dos discursos contemporâneos (LIMA, 2018).

\section{Os Significados da Rua para os Praticantes do Vôlei de Rua}

Indagamos os agentes sobre a rua, como significado específico pelas mediações culturais e os significados e sentidos da prática do vôlei de rua na vida dos seus agentes/praticantes. Para identificarmos estas questões perguntamos: O que o vôlei de rua significa para sua vida? Quando eu falo a palavra Rua, descreva o que vem à cabeça? Quais significados a rua tem na sua vida ou do esporte?

\footnotetext{
Me lembro da rua como um momento de lazer e diversão, eu brincava muito na rua, meus melhores amigos hoje são meus vizinhos da infância, nos lembramos tanto das nossas brincadeiras de rua, falar ou pensar na rua e lembrar dos melhores momentos da minha vida, e hoje voltar para rua jogando um esporte que eu tanto amo é incrível, tenho hoje muito respeito pela rua, hoje não é como antes, temos medo de estar na rua, mas o vôlei de rua fez com que eu relembrassem minha infância, encontrei muitos dos meus amigos voltando a jogar vôlei de rua, não quero deixar de jogar na rua, hoje levo meus filhos, minha esposa para os jogos, meus filhos adoram, por que normalmente não deixamos eles ficarem na rua sozinhas, e através do vôlei de rua posso fazer isso. [...] ah! "hoje eu até ganho dinheiro jogando, melhor ainda" (Narrador 4).
}

Identificar e analisar as principais mediações culturais que permeiam o vôlei de rua, não é tarefa fácil, pois podemos observar na fala do narrador 4 , a diversidade de mediações culturais que fazem do objeto do nosso estudo tão importante, por dar vários 
caminhos distintos, mas com um único objetivo fazer do vôlei de rua palco e mediador das manifestações culturais. O narrador 4, relembra da rua como um espaço de lazer e diversão, faz buscar na memória a infância, as brincadeiras na rua e os amigos que nos dias atuais continuam sendo amigos e vizinhos; relata também que voltar às ruas que hoje é motivo de preocupação e medo de estar nela, voltar para jogar vôlei de rua, o esporte que tanto adora, encontrar os amigos, trazer a família e, mais ainda poder ganhar dinheiro com as vitórias acumuladas nas etapas que vem disputando.

[...] a rua me lembra o ir e vir, de acesso rápido, na minha infância não pude ficar muito na rua, morava em apartamento não tive essa chance, mas jogar na rua me fez perceber o quanto a rua tem várias funções, e aqui somos famosos, as estrelas, sempre temos público assistindo (Narrador 3).

Ao contrário do narrador 4, o narrador 3 tem a visão da rua como um instrumento de utilização, o de ir e vir de pessoas, carro e principalmente o acesso rápido, sua infância foi pautada pelo o medo da violência das ruas, por isso seu ir para a rua esteve limitado, quando surge a oportunidade de participar de uma etapa de vôlei de rua, sendo ele jogador de voleibol de quadra, se surpreende com as múltiplas funções que a rua pode designar, o vôlei de rua, estas mediações são pertinentes à nossa pesquisa, pois revela os motivos reais e imaginários das manifestações culturais que o vôlei de rua pode proporcionar.

Aí é uma coisa muito profunda, né. É rua, eu acho que hoje, é uma das coisas, inclusive, músicas, até com a palavra rua, ela nos dá um ... entendimento ai, de tanto de liberdade como de prisão, né. Porque se você pega, por exemplo, igual nós tamos conversando sobre este cunho de, de pessoas que podem ser estabelecidas ao esporte e que podem praticar o esporte, não só essas pessoas que são menores carentes ou talvez pessoas que são delinquentes, mas pessoas normais mesmo. Pessoas da sociedade eles podem vim também a praticar o esporte, o vôlei de rua e o vôlei de quadra, o vôlei de areia, mas especificamente o vôlei de rua é nossa vontade, porque eles também vão estar fazendo um bem terrível prás suas vidas. Eles vão está fazendo um bem pra saúde quem pratica esporte, voltando a falar, talvez vá adoece, mas a demora é 
maior de quem não pratica, você entende. Cientificamente até inclusive a comunidade médica, ela nos explica isso, que quando você prática exercício físico o seu corpo produz a água oxigenada dentro da corrente sanguínea. Ela consegue a [...] matar células propicias a serem cancerígenas, então quer dizer, é um bem terrível pra quem pratica qualquer tipo de esporte, entendeu. Não importa se é vôlei, futebol de salão ou se é basquete ou qualquer um. Vai ser benéfico pra nossa resistência, pra nossa saúde. Evidente, com responsabilidade porque se você também prática de qualquer maneira, vai ser maléfica, entendeu. Então, tem de ser de certa forma com alguma orientação, por isso que eu acho que deveria virar lei, porque se virar lei. A lei tem coisas a respeitar também, não é de qualquer jeito, entendeu, pra pessoa também não se lesionar, não vim ter um problema, né. Crianças não ficar até tarde da rua envolvida só com isso, né. Larga de estuda, pra... pra ...poder ter envolvimento só com isso. Então seria superinteressante se a gente conseguisse que isso virasse um projeto de lei, entendeu. Eu me dou totalmente se for prá lutar a respeito disso daí, entendeu (Narrador $5)$.

Liberdade, prisão, crianças carentes, espaços de realização de atividades ligadas

à saúde e ao lazer são sentidos da rua para o narrador 5 .

A todo mundo fala assim, mas porque vôlei de rua. Vôlei de rua não tem, eu conto, tem os dois lados, aquele trabalho que você faz um mês antes pra chegar no nível, que é fazer divulgação que é ir na imprensa, ir na rádio, ir na Semov, pra trancar a rua, a gente vai na polícia pra pedir coisa... você tem de arrumar, corre atrás dos matérias, pra você poder fazer o serviço e... Ah! Bom, rua no aspecto social já a educação nossa que fala assim, rua é lugar de coisa que desocupado, de quem não tem o que fazer, mas pra nós dentro do vôlei. Vôlei de rua é um lazer, é uma forma de a gente extravasa um pouco todas as coisas da semana, você vai lá de você extravasa, de você jogar prá fora todas as coisas, as agruras da semana que você passa (Narrador 5).

Para o entrevistado, a rua tem diversos significados e sentidos, desde o espaço de pessoas "desocupadas", ao espaço de lazer, diversão, socialização e expressão das emoções.

Percebemos nos relatos que os participantes, jogadores e atletas, empoderam-se ao tomar para si o espaço da rua. No caso do vôlei de rua a lógica se inverte, a autoridade passa a ser o jogador. 
Conforme o roteiro de entrevista com o organizador, o narrador 1, relata sua trajetória e sua vasta experiências com a modalidade de voleibol de quadra e com o acompanhamento do início do vôlei de rua em Cuiabá e na região metropolitana; o narrador nos revela a dificuldade que foi continuar um projeto da AEVR, sem a presença do seu idealizador o Délio Lima, que no início de 2015 veio a falecer; ele além de adorar o esporte, articulava muito bem as relações entre patrocinadores, meio político e jogadores, o pós Délio foi de declínio para o vôlei de rua. No final deste mesmo ano, um grupo de jogadores e árbitros se encontram para homenagear o Délio Lima com uma etapa comemorativa. Contou com a participação de 36 trios, com a demanda superior ao esperado, a etapa que era para acontecer em um dia, ocorreu em dois dias, resgatando o vôlei de rua. O narrador 1 apresenta aqui informações importantes de como e onde ocorreu uma das primeiras etapas, em Várzea Grande -MT. Em meados de 2005 um grupo de amigos e jogadores de voleibol de quadra decidiram fazer um torneio, e titularam o mesmo de pirata, no rol de eventos que não acontecem através de uma federação ou associação, e sim por interessados em jogar.

[...] entendo que a rua ela é mediadora de vários aspectos culturais da sociedade contemporânea, ela sempre foi mais em especial hoje ela se torna mediadora de vários aspectos, muitas vezes a gente pensa que a rua é espaço apenas de trânsito e esquece que a rua também é um espaço de lazer (Narrador 1).

[...] aí trazer para rua o vôlei é fazer da rua um espaço mais democrático (Narrador 2).

É importante destacar que a mediação cultural permite construir e reconstruir novas significações através das interações, contatos, sensibilização, apreciação, participação e crítica. Segundo Ott (1997), os conteúdos da arte podem ser associados aos temas sociais, culturais e outros, na educação, visto que a "arte é um poderoso e 
significativo meio de comunicação na sociedade contemporânea" (OTT, 1997, p. 112). Acreditamos que o esporte, no caso aqui em análise, o vôlei de rua, pode constituir um espaço para ações/práticas/atitudes que possibilita a análise, a compreensão, a intervenção, a interpretação e o restabelecimento de referências dos códigos culturais da sociedade pós-moderna.

Segundo Lima (2018), a identificação da sociedade contemporânea e suas relações sociais mediam os variados aspectos da cultura local ou da rua, desvenda o ponto determinante do objetivo geral desta pesquisa, constatando que nos diversos caminhos relatados pelos agentes entrevistados, houve a demonstração da utilização da rua como espaço democrático, da escolha de cada indivíduo, sendo para o lazer, ir e vir e para o esporte. O vôlei de rua revela através da sua prática a configuração democrática, sobre utilização destes espaços de lazer para uns, e de disputa para outros. Neste interessante relato o narrador 1, conta que historicamente como nasce o vôlei de rua em Cuiabá e na região metropolitana e o entendimento da difusão da modalidade de vôlei de rua.

Os aspectos mediadores desta prática vão além das quatro linhas, como identifica o narrador 1; quando ele cita que ao retomar com os eventos, vários participantes, jogadores e atletas disseram estarem muito felizes com a retomada, trazia benefícios para uma vida saudável, pela relação amigável e o movimento econômico na comunidade que recebe na rua uma modalidade esportiva, o relato confidência os conflitos e as disputas pelo poder, gerando algumas contradições com relação à arbitragem, parecendo ser inerente ao ser humano querer sempre vencer.

[...] o vôlei de rua ele tem suas regras próprias e pode inclusive, ser alteradas, né. Dependendo do que é acordado antes, entendeu. Para que fiquem mais limpa assim a brincadeira ou a competição, o torneio (Narrador 2). 
O narrador 1, corrobora quando destaca que as regras da rua, dependem de um acordo antecipado de ambas as partes, os jogadores, organizadores e árbitros.

O vôlei de quadra ele tem uma denotação da marcação, o tamanho, a espessura, o tamanho da quadra, né. Ela é um pouco maior, né. Até porque jogam mais atletas, são seis atletas no ... vôlei de quadra e... no vôlei de rua são três, geralmente é trio, né. Inclusive, nós até fizemos algumas sugestões outras vezes, para ser de quarteto mas fica pequeno a rua, já não fica tão legal. Então essa é uma das diferenças. Existem outras diferenças na marcação, né. A lei que faz na hora ali, a regra que é acordado antes de acontecer a brincadeira ou até mesmo no torneio, é acordado ali, não pode conduzi a bola de uma maneira que lá no jogo, na quadra é diferente, né. Igual no vôlei de... areia, por exemplo, a maneira de você levantar é diferente, você não pode tocar de mão aberta, você tem de fechar a mão para tocar na bola, senão é condução. Então são algumas dessas é... regras que são diferentes também no vôlei de rua, né. Ali você a... marcação é um meio fio, lá na quadra é a linha pintada, né. Então tem algumas diferenças assim no vôlei de quadra (Narrador 2).

No discurso acima o narrador 2, evidência as diferenças e as dificuldades entre regras e espaço entre voleibol de quadra e vôlei de rua, descrevendo que a marcação de linha que irá delimitar se está fora ou dentro, fica localizada exatamente no meio fio, por mais inapropriada que seja a rua para essa prática de esportiva poucas são as lesões graves existente nesta modalidade. O que ocorre muito são as dificuldades com a respiração, o espaço aberto fica à exposição ao sol, vento e chuva, mas o jogo não para por estes motivos (LIMA, 2018).

O narrador 1, descreve a força das mediações culturais, os fatores mediadores, como o tempo, espaço, atletas, ambiente e interesses diversos, sendo que a maioria dos participantes, tanto jogadores quanto organizadores são oriundos do voleibol de quadra e hoje são adeptos ao vôlei de rua. 


\section{Considerações Finais}

O artigo tratou do vôlei de rua em Cuiabá/MT como fenômeno sociológico. Procurou desvendar os componentes mediadores do vôlei de rua, bem como identificar os interesses de seus praticantes em Cuiabá/MT, além de evidenciar as histórias de vida de agentes sociais que constroem uma trajetória do lazer, ocupando os espaços comunitários, bairros e as ruas do centro urbano de Cuiabá/MT. A pesquisa buscou também traçar o perfil dos praticantes de vôlei de rua, diferenciar o vôlei de rua do vôlei de quadra e analisar as formas de sociabilidades e disputas em torno dos eventos e jogos de vôlei de rua.

Os resultados obtidos nesta investigação apontaram percepções interessantes acerca dos aspectos mediadores do vôlei de "rua" em Cuiabá-MT. Podemos destacar que esta prática social no tempo presente, evidencia percursos culturais diversos, de acordo com cada narrativa colhida pelos agentes entrevistados, na prática do vôlei de "rua".

Ao pesquisar e conduzir nossa investigação através da indagação inicial, a problemática da presente pesquisa revelou o longo caminho que percorremos. Quais estratégias delineiam as maneiras de fazer o "Vôlei de Rua" na cidade de Cuiabá e no Mato Grosso?

A partida em busca dos caminhos ou trajetórias das maneiras de fazer o jogo de vôlei de rua, foram desenvolvidas, através da entrevista oral, constituída por relatos da história de vida desse conjunto de agentes. Dessa maneira, desvendamos o começo, a fundação da associação de vôlei de rua e as mediações ali evidenciadas para que chegássemos às diversas maneiras de relacionar os participantes, jogadores e atletas e a rua. Aprofundamos mais ainda quando nos depararmos com intensa participação da comunidade ao redor de onde acontecem as etapas de vôlei de rua, observando - por exemplo - que a vida na rua, como podemos constatar, faz com que a comunidade 
ganhe outro ritmo nos dias das etapas de vôlei de rua, e o cotidiano da rotina caseira quebra-se e transformava outras rotinas que a rua se completava com algo diferente e novo no ambiente tão familiar. Mas, sobretudo, os relatos que começaram com a idealização desta hibridação da modalidade de voleibol, foram se aproximando do momento atual, de maneira que cada entrevistado pôde - ao menos por alguns minutos - parar e refletir sobre os fatos mediadores da prática de vôlei de rua, praticado ora por lazer ora por disputas e as relações daí advindas. Muitos sentimentos se enviesaram nessas reflexões, à exceção da indiferença.

Entre todos os que participaram das entrevistas, desvendamos ao perceber saudades da infância, alegrias, vitórias, derrotas, decepções, rivalidade, coragem, companheirismo, menos a indiferença. Há um sentimento de afeto pelo vôlei de rua na cidade de Cuiabá/MT e na região metropolitana. Cada qual amando a sua própria história de vida, e o que o voleibol trouxe para cada um deles, e hoje o reencontro através da hibridação do vôlei de rua. Fato evidenciado quando alguns revelaram o desejo da continuidade das etapas, incluídas outras manifestações da cultura popular, de dar nova vida às ruas ali existentes. Novas maneiras de fazer aquele cotidiano. Novas, porque em outro território foi (trans) formado, como consequência daqueles embates sociais. Evidenciamos que a conectividade ultrapassa as demarcações territoriais e sociais, cujo laço de manutenção reside nas diferenças, que são múltiplas, desde as maneiras cotidianas de fazer o vôlei de rua às aceitações de grupos sociais distintos, das diversidades religiosas e de gênero, como é o caso da presença de alguns jogadores serem homossexuais.

Dentro dos próprios relatos podemos perceber claramente as diferenças discursivas; uns mais conservadores ou resistentes, outros mais receptivos ao 
desconhecido, ao novo. Mas o fio condutor de todos os conflitos, provocador da ruptura ressignificante, reside naquele ato de expor publicamente o nome de jogadores que antes na quadra não tinham nenhuma relevância e no ambiente da rua (vôlei de rua) serem os reis da rua. Se ali existiu alguma hierarquização, ela se evidenciou na questão "habilidade", porque todos os agentes - em geral e com poucas exceções - advêm de um quadro socioeconômico que os situa em mesmo nível mantendo, assim, o mesmo capital simbólico.

Nesse sentido, voltando um pouco à história do espaço de lazer, percebemos que as táticas de jogo social foram passando - de período a período - por atividades variadas. Como exemplo, houve um período de evidência para a atividade de vôlei de areia, futevôlei, depois foi o vôlei de rua que alcançou certa notoriedade, inserindo-se na história cuiabana desse esporte. Como consequência, têm estimulado o surgimento e a manutenção da economia local, a venda de produtos alimentícios e principalmente as inter-relações pessoais entre os diversos agentes. Pelos relatos colhidos, sentimos que o vôlei de rua em Cuiabá/MT, vem ressurgindo, ainda que timidamente, através de um ou outro que mantém as etapas e as mediações culturais. Na teia cultural que, seguramente, há de possibilitar novas relações de força, como estratégia geral de permanência dos jogos de poder social existentes na rua. Talvez filhos e filhas, netos e netas, desde já, estejam se preparando para o retorno à rua, naquelas diversas comunidades, em busca de novas maneiras de fazer e resolver seus conflitos, tendo-se por apito inicial a vontade de (re) começar.

Talvez, uma vez mais, e assim o esperamos, a prática sócio esportiva do vôlei de rua, sirva outra vez, de mediador silencioso ou gritante que ramifica as infinitas possibilidades de ser, estar e utilizar a rua como forma de manifestações culturais e 
mediadas. Como sugestão de novas ações das modalidades esportivas contemporâneas, podemos destacar a divulgação e incentivo de políticas públicas que possam atender as demais atividades alternativas com intuito de atender a demanda social esportiva que as comunidades necessitam; em especial no caso desta pesquisa, o vôlei de rua, com as contribuições dos diversos relatos orais dos seus agentes protagonistas da prática do vôlei de rua em Cuiabá/MT.

\section{REFERÊNCIAS}

BARBERO, M. J. As formas mestiças da mídia. Pesquisa FAPESP Online, edição 163, p. 10-15, setembro 2009, Entrevista concedida à Mariluce Moura. http://revistapesquisa.fapesp.br/2009/09/01/as-formas-mesticas-da-midia/.

. M. j. Dos meios às mediações: Comunicação, Cultura e hegemonia. Tradução,

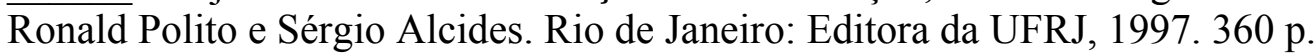

M. J. América Latina e os anos recentes: o estudo da recepção em comunicação social. In: SOUSA, M. W. (Org.). Sujeito, o lado oculto do receptor. São Paulo: Brasiliense/ECA-USP, 1995, p. 39-68.

BOAS, F. Antropologia cultural. Org. Celso Castro. Rio de Janeiro: Jorge Zahar, 2004. 112 p.

BOURDIEU, P. Os usos sociais da ciência: por uma sociologia clínica do campo científico. São Paulo: UNESP, 2004a. 86 p.

BOURDIEU, P. Razões práticas: Sobre a teoria da ação. Tradução de Mariza Corrêa. Campinas: Papirus, 2011, 232 p.

O poder simbólico. Rio de Janeiro: Bertrand Brasil, 2003, 314 p.

A Economia das Trocas Linguísticas: O que falar quer dizer. São Paulo: Edusp, 1996a. 192 p.

A economia das trocas simbólicas. 3. ed. Org. Sergio Miceli. São Paulo: Perspectiva, 1992. $367 \mathrm{p}$.

Razões práticas: Sobre a teoria da ação. Irad. Mariza Corrêa. Campinas: Papirus, 1996b. 232 p.

- Coisas Ditas. Tradução Cássia R. da Silveira e Denise Moreno Pegorim. Revisão técnica Paula Monteiro. São Paulo: Brasiliense. 2004b. 235 p. 
. Questões de sociologia. Rio de Janeiro: Marco Zero. 1983. 289 p.

CAUNE, J. Pour une éthique de la médiation: Le sens des pratiques culturelles. SaintMartin d'Hères: PUG, 1999. 294 p.

DENZIN, N. K. Interpretive biography. Newbury Park: Sage, 1989. 160 p.

GEERTZ, C. A interpretação das culturas. Rio de Janeiro: Zahar, 1973. 214 p.

HATCH, J. A..; WISNIEWSKI, R. Life history and narrative: questions, issues and exemplary works. In: HATCH, J.; WISNIEWSKI, R. (Ed.). Life history and narrative. London: Routledge Falmer, 1995. p. 113-135.

LAMIZET, B. La médiation culturelle. Paris: L’Harmattan, 1999. 448 p.

LARAIA, R. de B. Cultura: um conceito antropológico. Rio de Janeiro: Zahar, 1986. $116 \mathrm{p}$.

LIMA, C. M. de. Vôlei de Rua em Cuiabá e os aspectos mediadores da Cultura Contemporânea. Dissertação de Mestrado [Programa de Pós-Graduação em Estudos de Cultura Contemporânea], Universidade Federal de Mato Grosso, Cuiabá, 2018. 122 p.

OTT, R. Ensinando crítica nos museus. In: BARBOSA, A. M. Arte-educação: leitura no subsolo. São Paulo: Cortez, 1997, p. 36-52.

QUEIROZ, M. I. P. Relatos orais: do "indizível” ao "dizível”. In: SIMSON, O. M. V. (Org.). Experimentos com histórias de vida: Itália-Brasil. São Paulo: Vértice, 1988. p. 14-43.

STIGGER, M. P. Esporte, lazer e estilos de vida: um estudo etnográfico. Campinas: Autores Associados, 2002. 278 p.

TYLOR, E. B. Primitive Culture. Inglaterra: Gordon Press, 1871. 501 p.

VELHO, G. \& VIVEIROS DE CASTRO, E. O conceito de cultura e o estudo das sociedades complexas. Cadernos de Cultura. USU (Universidade Santa ÚrsuIa), ano 2, $\mathrm{n}^{\mathrm{o}} 2$, Rio de Janeiro, 1980.

\section{Endereço dos Autores:}

Francisco Xavier Freire Rodrigues

Rua Nemelice Gaiva de Almeida, 202, Apto. 101-E

Residencial Portal do Rio - Bairro Ponte Nova

Várzea Grande - MT - 78.115-150

Endereço Eletrônico: fxsociologo@yahoo.com.br

Caroline Maria de Lima

Rua Caldas Novas número 19, quadra 13 - Jardim Gramado 
Francisco Xavier Freire Rodrigues e Análise Sociológica sobre a Prática do Vôlei de Rua em Cuiabá/MT Caroline Maria de Lima

Cuiabá - MT - 78.085-490

Endereço Eletrônico: caroline_maria@hotmail.com 